\title{
Interleukin 2 Receptor Subunit Beta Measurement
}

National Cancer Institute

\section{Source}

National Cancer Institute. Interleukin 2 Receptor Subunit Beta Measurement. NCI

Thesaurus. Code C142283.

The determination of the amount of interleukin 2 receptor subunit beta present in a sample. 